\title{
Spirituality review on mental health and psychiatric nursing
}

\author{
Revisão de espiritualidade em enfermagem de saúde mental e psiquiatria \\ Revisión de espiritualidad en salud mental y enfermería psiquiátrica
}

\section{Gabriel Lavorato Neto', Larissa Rodrigues', Diego Alexandre Rozendo da Silva", Egberto Ribeiro Turato", Claudinei José Gomes Campos'}

' Universidade Estadual de Campinas, Faculdade de Enfermagem. Campinas-SP, Brasil.

"Universidade Estadual de Campinas, Faculdade de Ciências Médicas. Campinas-SP, Brasil.

\author{
How to cite this article: \\ Lavorato Neto G, Rodrigues L, Silva DAR, Turato ER, Campos CJG. Spirituality review on mental \\ health and psychiatric nursing. Rev Bras Enferm [Internet]. 2018;71(Suppl 5):2323-33. \\ [Thematic Issue: Mental health] DOI: http://dx.doi.org/10.1590/0034-7167-2016-0429
}

Submission: 10-26-2016 Approval: 08-06-2017

\begin{abstract}
Objective: Gather the concepts, theories and interventions about spirituality, its nature and functions in mental health and psychiatric nursing. Method: A literature review proceeded on February 2016. It has integrated 214 studies published until December 2015 by crossing Spirituality and Psychiatric Nursing mesh terms in databases. Results: Conceptualization about spirituality and religion, their complexity in nursing research, education, and clinical approach; their functions to human being correlated to the purpose of life, transcendental connections, and support in mental health; the professional boundaries in address to spirituality in mental health scenery, and a descriptive literature recommendations and a instruments catalog. Conclusions: Spirituality in nursing mental health and psychiatry remains a theoretical problem, and has a clinical mischaracterized approach; recently publications try to promote a human and holistic trend in the practice, as a challenge to lead the current circumstances to valid nursing bases.
\end{abstract}

Descriptors: Spirituality; Psychiatric Nursing; Mental Health; Holistic Nursing; Religion.

\section{RESUMO}

Objetivo: Colecionar os conceitos, teorias e intervenções sobre espiritualidade, sua natureza e funções em Enfermagem de Saúde Mental e Psiquiatria. Método: Uma revisão Integrativa da literatura realizada em fevereiro de 2016. Foram integrados 24 estudos publicados até Dezembro de 2015 obtidos pelo cruzamento, nas bases de dados, dos descritores Espiritualidade e Enfermagem Psiquiátrica. Resultados: Obteve-se a conceituação sobre religiosidade e espiritualidade, suas complexidades na pesquisa, educação e abordagem clínica em enfermagem; suas funções para o ser humano ligado ao propósito da vida, às conexões transcendentais, e ao suporte em saúde mental; os limites profissionais do manejo de espiritualidade no cenário de Saúde Mental; e uma descrição das recomendações da literatura com um catálogo de documentos. Conclusão: A Espiritualidade na Enfermagem Psiquiátrica e de Saúde Mental permanece um problema teórico com uma abordagem clínica empobrecida; recentemente as publicações tentam promover uma tendência de prática humanizada e holística como um desafio de mover a atual circunstância para bases válidas em enfermagem.

Descritores: Espiritualidade; Enfermagem Psiquiátrica; Saúde Mental; Enfermagem Holística; Religião.

\section{RESUMEN}

Objetivo: Reunir los conceptos, teorías e intervenciones sobre la espiritualidad, su naturaleza y funciones en la salud mental y la enfermería psiquiátrica Método: En febrero de 2016 se realizó una revisión de la literatura. Se han integrado 214 estudios publicados hasta diciembre de 2015 mediante el cruce de los términos de la malla de Espiritualidad y Enfermería Psiquiátrica en las bases de datos. Resultados: Conceptualización sobre espiritualidad y religión, su complejidad en la investigación, la educación y el enfoque clínico de la enfermería; sus funciones para el ser humano se correlacionan con el propósito de la vida, las conexiones trascendentales y el apoyo en la salud mental; los límites profesionales en dirección a la espiritualidad en el escenario de salud mental, y recomendaciones descriptivas de literatura y un catálogo de instrumentos. Conclusión: La espiritualidad en la salud mental y la psiquiatría de la enfermería sigue siendo un problema teórico y tiene un enfoque clínico 
mal caracterizado. Recientemente, las publicaciones intentan promover una tendencia humana y holística en la práctica, como un desafío para llevar las circunstancias actuales a bases de enfermería válidas.

Descriptores: Espiritualidad; Enfermería Psiquiátrica; Salud Mental; Enfermería Holística; Religión; Cuidado de Enfermería.

\section{CORRESPONDING AUTHOR Gabriel Lavorato Neto E-mail: lavorato.neto@gmail.com}

\section{INTRODUCTION}

Acute patients in mental health treatment often have disorders that affect their spiritual and religious perceptions in correlation to themselves and life ${ }^{(1)}$. There is a similarity between psychotic episode and mystical state ${ }^{(2-3)}$ and that causes estrangement. The classic literature in psychopathology is rich of cases reporting the content of mystical delirium, and how Psychiatry attempted to explain the experiences of religious figures in psychopathological terms ${ }^{(4)}$. In addition, the unclear distinction between spirituality and religion ${ }^{(5)}$, and the damages or benefits that they can cause to mental health takes place in the literature ${ }^{(6)}$ leading them to an obscurity function.

The professionals who meet service users that expose their needs in this dimension deal with the drama on how to address them; this is not just in reference to acute patients. It is common that people in the process of mental health recovery search for spiritual support ${ }^{(3)}$, what implies the same professional conflict about the task to discern the consequences of this search to such patients. How to lead and address the spiritual issues of service users is a matter that requires knowledge of the cultural context ${ }^{(7-8)}$, psychopathological conditions and psychological implications ${ }^{(1,9)}$, an ethical appreciation ${ }^{(10)}$, and technical preparation based on evidence balanced with the art of caring ${ }^{(3)}$.

Spirituality in health science remains a hard question that touches the limits of methodological objects delineations, although its use and presence is largely employed on multiple therapeutic models and theories which also influence the caring ${ }^{(6,11)}$. Placed in such pressure zone between classic psychopathological heritage and challenged for its holistic bases ${ }^{(5,8)}$, the caring science attempts to answer the new demands of mental health in an evidence based context to lead the spiritual issues.

Considering the importance of the theme to caregivers of Mental Health, and the plurality of answers, the implications of those trends in a humanistic and holistic approach to a human being, the problematic cross-cultural caring in cosmopolitan areas, this Integrative Review exposes the concepts; practices interventions and assessment questions; limits; theories and models; and implications on how the spirituality theme is taking off in the mental health care field.

\section{OBJECTIVE}

To collect the evidence available for field researchers, expertize theoretical explanations, and know-how experience. It is expected that the results could give support to clinical practices and the nursing education area, in a manner to demonstrate the actual state of discussion on the theme, providing a condensed view of scientific material about it in the Mental Health and Psychiatry Caring fields in order to reflect the trends and to provide references.

\section{METHOD}

The adopted methodology was a integrative review ${ }^{(12)}$ aimed to summarize the previous literature produced until December 2015 , by combining the knowledge of sources with different methodological designs, and to focus the various perspectives on the management of spirituality phenomenon in a holistic and humanized nursing mental care to patients. Between January and February 2016, a total of 214 studies were found by crossing their mesh terms that matched Spirituality and Psychiatric Nursing in the following databases now broken with the respective number of studies therein contained in parentheses: BIREME/ BVS (0), Medline/Pubmed (35), Embase (48), Lilacs (0), Scopus (47), Cinahal (56), Psycinfo (9) and Web of Science (19).

Based on this outcome with duplicates excluded, studies that met the following criteria were selected to the analytical process (Figure 1): field studies with nursing staff of psychiatry or mental health caring; theoretical, reflective or opinion studies produced by expert authors of the mental health nursing field; studies with the theme centered on the relationship between spirituality and psychiatric or mental health caring. The exclusion criteria was implemented as follows: duplicate studies on the bases and by reading the titles and abstracts were excluded; also excluded from the sample were those who aimed to promote some kind of belief or specific faith above the research related to caring; or those where the issue of mental health involved was due to other health complications; even the journal editorials and unavailable studies for electronic consultation.

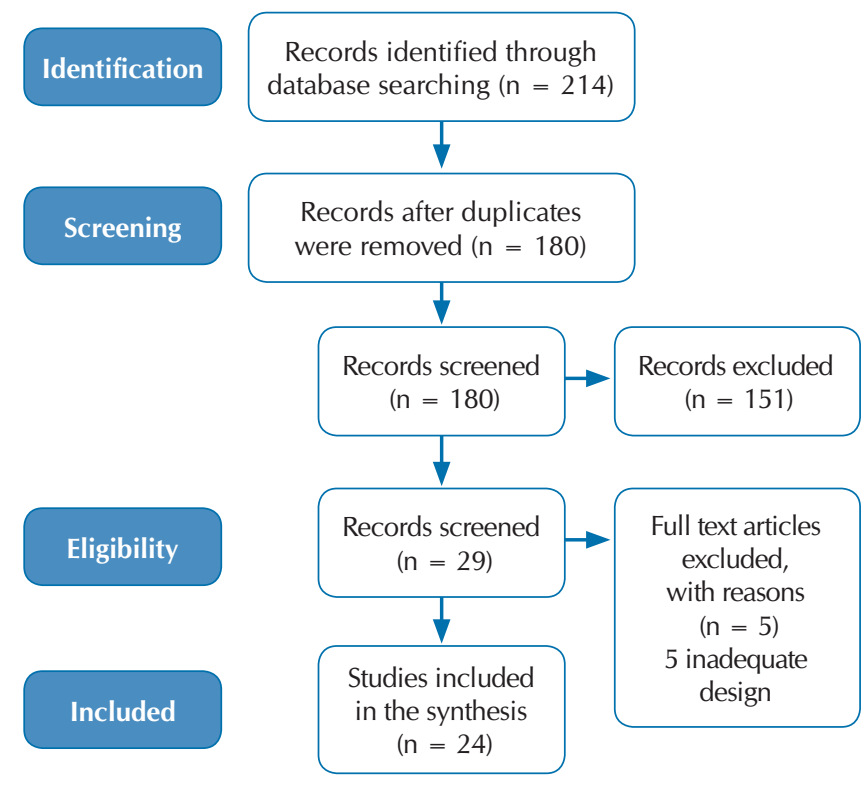

Figure 1 - PRISMA 2009 flow diagram 


\section{RESULTS}

As a result of the search process, selection and election of the studies, 24 (Chart 1) were read and classified into a spreadsheet according to its own design (respected the designation of the design described in the study), purposes, main methodological properties and results.

The analysis was done by following the steps proposed by Whitmore \& Knafl(12): the researcher read each one of the primary sources and data were extracted and tabulated according to its source of study; a citation was made with its correspondent thematic classification designated by the investigator, and the kind of evidence demonstrated by the author to support the claim (literature and its kind, empirical, experience, theoretical basis). After this, the group categories were confronted by syllogistic and parallelistic constructions. Finally, the material was synthesized in properties and procedures relating to the provision of the answer to our research question as: Conceptualization about spirituality and religion, their complexity in nursing research, education, and clinical approach; their functions to human being correlated to the purpose of life, transcendental connections, and support in mental health; the professional boundaries in address to spirituality in mental health scenery, and a descriptive literature recommendations and a instruments catalog: Each category is descrambled and discussed below.

Chart 1 - Studies Inform

\begin{tabular}{|c|c|c|c|c|}
\hline Year & Country & Author & Design & Sample \\
\hline 1996 & USA & Pullen L, Tuck I, Mix K. ${ }^{(13)}$ & Descriptive (Cross Sectional) & $\begin{array}{l}\text { Mental health nurses of a public } \\
\text { facility }(n=50) \text {. }\end{array}$ \\
\hline 1997 & USA & Tuck I., Pullen L., Lynn C. ${ }^{(14)}$ & Descriptive (Cross Sectional) & Mental health nurses $(n=50)$. \\
\hline 1997 & UK & Nolan, P. and Crawford, P. ${ }^{(15)}$ & Reflection Article & \\
\hline 1999 & USA & Aftonomos S..$^{(16)}$ & Experience Report & \\
\hline 2001 & USA & Tuck I, Pullen L, Wallace D. ${ }^{(17)}$ & $\begin{array}{l}\text { Descriptive-comparative (Cross } \\
\text { Sectional) }\end{array}$ & $\begin{array}{l}\text { Mental Health Nursing }(\mathrm{n}=91) \\
\text { Parish Nursing }(\mathrm{n}=95)\end{array}$ \\
\hline 2001 & UK & Greasley P., Chiu L.F., Gartland M. ${ }^{(18)}$ & Qualitative & Nine Focus Groups $(n=9)$. \\
\hline 2002 & UK & Thompson, I. ${ }^{(5)}$ & Literature Review & \\
\hline 2003 & UK & Eeles, J., Lowe, T. and Wellman, N. ${ }^{(9)}$ & Literature Review & Six articles $(n=6)$. \\
\hline 2003 & USA & Cox T. ${ }^{(10)}$ & Theoretical & \\
\hline 2004 & USA & McLaughlin, D. ${ }^{(3)}$ & Theoretical & \\
\hline 2004 & USA & O'Reilly M.L. ${ }^{(19)}$ & Theoretical & \\
\hline 2005 & SWE & Koslander, T. and Arvidsson, $\mathrm{B}^{(20)}$. & Qualitative & Nurses in psychiatric care $(\mathrm{n}=12)$ \\
\hline 2006 & USA & Mohr, Wanda K. ${ }^{(1)}$ & Literature Review & Literatures $(n=56)$. \\
\hline 2007 & USA & Schuhow D.A. ${ }^{(21)}$ & Theoretical & \\
\hline 2007 & UK & $\begin{array}{l}\text { Brimblecombe, N. and Tingle, A. and } \\
\text { Tunmore, R. and Murrells, T. }{ }^{(22)}\end{array}$ & National open consultation & Nurses network $(\mathrm{n}=327)$. \\
\hline 2007 & USA & Baumann, S.L. ${ }^{(23)}$ & Theoretical & \\
\hline 2010 & USA & Stuart GW. ${ }^{(8)}$ & Reflection Article & \\
\hline 2011 & UK & Elliott, Ruth. ${ }^{(24)}$ & Qualitative & Psychiatric Nurses $(n=14)$. \\
\hline 2012 & BRA & $\begin{array}{l}\text { Murakami, Rose and Campos, } \\
\text { Claudinei José Gomes. }{ }^{(25)}\end{array}$ & Literature Review & $\begin{array}{l}\text { Thirteen papers were integrated } \\
\qquad(\mathrm{n}=13) .\end{array}$ \\
\hline 2013 & UK & Ledger, Peter and Bowler, David. ${ }^{(26)}$ & Experience Report & \\
\hline 2013 & ZAF & Tokpah, M. M. and Middleton, $\mathrm{L}^{(27)}$. & Qualitative & Psychiatric nurses $(n=7)$. \\
\hline 2013 & USA & $\begin{array}{c}\text { Kilmer, Debra L and Lane-Tillerson, } \\
\text { Christal. } .^{(28)}\end{array}$ & Theoretical & \\
\hline 2014 & UK & Raffay, Julian. ${ }^{(7)}$ & Literature Review & $\begin{array}{l}\text { Database }(\mathrm{n}=43) ; \\
\text { Grey literature (published or not); } \\
\text { Tools }(\mathrm{n}=3 \text { : HOPE, FICA, FACT). }\end{array}$ \\
\hline 2015 & DEU & $\begin{array}{l}\text { Lee, Eunmi and Zahn, Anne and } \\
\text { Baumann, Klaus. }{ }^{(29)}\end{array}$ & $\begin{array}{l}\text { Descriptive-comparative (Cross } \\
\text { Sectional) }\end{array}$ & $\begin{array}{c}\text { Physicians }(\mathrm{n}=118) \\
\text { Psychotherapist }(\mathrm{n}=46) \\
\text { Nurses }(\mathrm{n}=148) \\
\text { Chaplains }(\mathrm{n}=124)\end{array}$ \\
\hline
\end{tabular}




\section{DISCUSSION AND DESCRAMBLING}

Spirituality and Religion: the comparing and distinction, nature, complexity and functions in mental health and psychiatry nursing

Mental Health Care literature about Spirituality and Religion is going through a process that tries to establish distinctions and similarities between both categories in matter of reflecting and to build a better approach of them to the clinical scene. This literature considers Religion and Spirituality as an elementary human need ${ }^{(1,20,22,29)}$, both of the same sphere of life's dimension, exercising an inner function in a person's life, important to be understood by carers ${ }^{(1,3,7,20-22)}$. Their formulation matter for the caring and needed attention in health and mental health, they are a need and this is their drawing in literature focus.

Spirituality and Religion, as an inner function in a person's life, are related to the establishment of transcendental connections in three ways: to the sacred, to the inner self, and to the common world of life; this modulates the symbolic experience of the meaning of life and of the events of life ${ }^{(1,9-10,14,19,25,27)}$. However, the employed effort to mark them equally as separated concepts aims to move the theme in order to cover a larger range of people in it: "there are those who are outside any categorization by belief system [...]. It would do a great disservice to a wide variety of ways of addressing spiritual matters if the term 'spiritual' was only connoted as being to religious matters"(5). Religion is one of the spirituality's elements ${ }^{(7)}$, a system of belief in a cultural context $\mathrm{t}^{(1,17,25,27)}$.

Two kinds of religions have been described in Mental Health literature in a contribution coming from the Psychology of Religion: the Extrinsic and the Intrinsic Religion. The first one is qualified by its social ends, disconnected from an inner sacred aim, what is a reduction in spiritual aspiration. It is connected with some social damages which practices are associated to a failure in the individual's personality development ${ }^{(23,25)}$. Differently, Intrinsic Religion is a concept closer to the spirituality's elements, genuine faith and psychological maturity ${ }^{(23,25)}$.

Some damages that religion could bring to mental health are those correlated to oppression and to fanaticism associated with extremist systems ${ }^{(25)}$, which reinforces intolerance and inequality, abuse of children, physical punishment, mortal and dangerous rituals $^{(1)}$. For this kind of faith, in which "is predicated on restrictive and punitive dogma, may impede the experience and healing potential of spirituality"(19). In psychopathological issues it is reported that "there is a higher prevalence of mental disorders in most religious" ${ }^{\prime 25)}$ as bipolar disorder and schizophrenia ${ }^{(1,25)}$. These authors also expose a group of negative effects on the health of religious individuals: treatment interruption or avoidance, cases of isolation or alienation. Authors are still cautious, they assert there are a few systematic studies sustaining these pathological affirmations, and it is necessary to evaluate them by debugging their biases. Balancing the question of the role of religion in mental health, Lee and colleagues concluded based on authors of their query: "apart from pathological symptoms in the disguise of religious phenomena, they often observe positive effects from religiosity/spirituality in mental health care"(29).

Spirituality is a question of meaning ${ }^{(1,3,8,10,18,23,25-27)}$, a human symbolic construction on the purpose of life that covers the whole existence in a holistic perspective; it works through a transcendental sense of connectedness that bridges the sacred and common worlds ${ }^{(8-9,26)}$. In a sacred way it expresses a connection with high powers, and deities ${ }^{(9-10,14,19)}$, and religion may participate here. Connection with the common world means interlinking with others and circumstances ${ }^{(10,14,19,27)}$. Certainly, Frankl's concepts ${ }^{(10)}$ of existential meaning and purpose of life have influenced both the mental health area and the nursing care field in it.

Authors agree that spirituality is also a complex cross culture issue what turns into a hard task to universalize its principals and the development of specific spiritual assessment tools. However, this sense of spiritual plurality is one of the most crucial aspects of caring in cosmopolitan areas once the spiritual individual's formation and his religion beliefs features affect the whole management of care $\mathrm{e}^{(1,5,7-9,15,24,27)}$.

Spirituality and Religion encapsulate intimate aspects of culture; therefore, it is necessary to dispense a special awareness to the client's value systems, sometimes expressed in religion or spiritual terms. They touch communication, hygiene, feeding and many other aspects requiring an ethical approach of nonjudgmental posture and tolerant climate ${ }^{(8)}$. In fact, Thompson quotes the inciting of Markham to "health professionals to become more sensitive to multiculturalism in the treatment of illness"(5), Thompson also says "it is only the individual who can supply another with the unique perceptions of his or her own spirituality".

Psychiatrically, spirituality and religion are a "complex issue $^{\prime \prime(7)}$, and "bizarre religious delusions is a question that plagues the novice as well as the expert mental health practitioner"(3). The question involves trends in research and education, and carers in mental health feel discomfort if "they are uncertain about the most suitable approach"(5). Furthermore, a circle of evidence in literature on spirituality and health has supported the importance and utility of it to individuals in mental health, and how effects of spirituality in life benefit emotions, connectivity and the construction of meaning in a holistic framework $(5,7,20,24)$.

A first benefit associated with an individual's inner function of spirituality in mental health could be named for its euthymic effect on the humor ${ }^{(18)}$, once that spiritual practice and experience are related with "provided inner strength", "comfort", "peace", "wellness", "wholeness", and "enhanced coping", "psychological well-being"(17). Well-being is the result of the interaction in a set of inner virtues cultivated in spiritual practices as "self-steam, hope, relatedness and connectedness of self to others and God"(5). Other aspects of the euthymic nature of spirituality are lower distress, coping for support healing, less anxiety, fewer depressive symptoms, wholeness face of emotional distress, lower risk of suicide, assurance ${ }^{(1,18-19)}$, and "able to endure debilitating feelings of guilt, anger and anxiety"(25), what brings a holistic healthier condition ${ }^{(1,3,5,19,22,25)}$.

Besides effects on humor, connectionless of sacred transcendental spiritual practices promotes a movement of the soul to search divinities, power and forces through rituals ${ }^{(3,5)}$ "that may exist within a person but is ultimately apart from him or her"(1). In addition, this is also a belonging sense to the universe and to the communities whereby rituals happen, what works as a source and structure of support and comfort alimenting the experience of faith, and gives the interaction of the symbolic 
system of life, by which individual forge the own experience of meaning and identity ${ }^{(18-19,21-22,26)}$. This experience empowers the individual and cultivates in him values as humanity, compassion, forgiveness, and love for the life's journey ${ }^{(5,26)}$. These phenomena which support that connectionless is a spiritual component in a tri-dimensional pathway of the individual's linking: with high symbolic world, the deep inner universe of spirit, and world of people and life. These three ways are also embraced for two qualities of symbolic perspectives, the sacred, and common; and transcendence is the rule over them all.

\section{Boundaries}

\section{Political, Educational, Scientific and Professional}

Studies point out some boundaries in the way of meeting spiritual needs of Mental Health People. There is an unique related report about a political action from Austrian Federal Ministry of Health in 2014 that "edited guidelines for psychotherapists to (re)establish boundaries against esoteric, spiritual and religious practices"(29). However, the study comments the fact in these terms: "the mere avoidance of religious/spiritual practice in therapeutic settings does not yet resolve the question".

In fact, to resolve the presence of spirituality in a mental health setting brings as a consequence a major discussion of its role in general health. The question crosses limits in knowledge and its trends, ethical concerns, services organization, clinical practice and professional training and characterization. A primary incisive consensus is that spirituality is a complex object of study ${ }^{(1,9,19,29)}$. O'Reilly states: "it is difficult to describe, let alone define"(19) after an inquiry to literature; Mohr problematizes: "is an amorphous and difficult concept, hard, or impossible to define"(1). The complexity of defining spirituality as an object touches the limits of contemporary methodological structures and science concept. However, the interest in spirituality in health, and Mental Health, is emphatic and "increasing"(26), what probably opened the scientific scene to reveal other kinds of boundaries in the way of meeting spiritual needs in mental health.

Discomfort about the issue has been related ${ }^{(5)}$, what needs to be explained in the light of other facts. There is an inconclusive scientific debate about the spirituality nature ${ }^{(3,13,15,18,24)}$, and a normative consequence that Educational Programs and training in nursing would be reflecting this contradictory tendency; therefore, it could be seen in care delivery, which has adopted the "most technological paradigm shift"(13) of our times. The effect in spiritual care in nursing role could be expressed as a conflict between the art of care and the science of care $^{(3)}$, since "traditionally the treating has been mechanics under allegedly a holistic approach, and spirituality is inadequately addressed, what means fails to the whole person"(24).

Spirituality in the nursing field implies a relation between research and education. On one side, research has already been developed covering spiritual nursing care in Polio, AIDS, Volunteering, Alternative Cures, Nursing Diagnoses, Cancer, Palliative Care ${ }^{(10,30)}$. Spirituality gain in mental health has been related in coping attitude for women abuse, or substances abuse problems $^{(3,23)}$; remission of Depression ${ }^{(1)}$, shorter hospital stays, life satisfaction ${ }^{(3)}$. On the other side, practitioners remain concerned on "crossing professional boundaries" in "addressing spiritual needs"(26), what suggests that research results have impacted training moderately. Without a consistent training, nursing staff "lacked confidence in exploring issues of a spiritual nature" and expressed difficulty "with the language used to talk about spirituality"(26). Consequently, "nurses report not having enough knowledge about this dimension to adequately address it; being unfamiliar with the diverse cultural and spiritual practices in contemporary society; fearing that spirituality might trigger psychiatric symptoms"(27), and this reported South African experience could be generalized to other cosmopolitan areas because it is an universal nursing challenge ${ }^{(8)}$.

These previously exposed factors could be joined to explain the recent nursing complaint of professional mischaracterization ${ }^{(7,18)}$. This in consequence opens the way to certain human feelings reported by nursing staff: "the most prevalent trend on nursing creates an environment about skills of interpersonal care as to some extent sidelined and devalued"(18); and a decreased perspective about the role of nursing involved in "lack of time and bureaucracy"(7).

If spirituality is considered a transcendent interconnection of people and meaning, all those factors and interest in a spiritual dimension, especially in health care, could be understood as how nursing is trying to find an equilibrium between its holistic humanistic-based traditions and its ulterior technical scientific development in a balance that could preserve the professional with an unique value of contribution to humanity ${ }^{(26)}$.

\section{Clinical Boundaries}

Clinical Boundaries are the ultimate limit to availed spirituality on Mental Health Care for its critical circumstances correlated with consequences of practices, psychiatric patient's conditions and clinical ethics. Mohr pointed out the concern about the response threshold of a health care professional, the conflict to determine whether there is valid evidence to a base treatment what reflects a struggle between beliefs, values, staff and patients ${ }^{(1,24)}$. Understanding that any spiritual comprehension perhaps starts with someone's own spirituality, this brings nursing to an uncomfortable position to make assessments of spiritual needs without bias ${ }^{(24)}$. These same authors answered an ethical base to those questions; that is, nursing mental health care is an area centered on the client's needs.

A second group pointed out clinical boundaries as far as the consequences on the client's health. Based on many authors, Baunmann states: "Not all religious beliefs and practices of spirituality are linked to health and well-being"(23). For that, it is necessary to take the question by the kind of results it could bring to the client's health. To give attention to the spiritual needs is to attend to important elements of a human being-personhood-but obviously to reinforce delusions is dangerous ${ }^{(1)}$ and not an ethical approach.

\section{Theoretical and clinical nursing staff responses to the spiri- tual needs in mental health and psychiatry fields}

\section{Negligence: the actual status of addressing spirituality needs on mental health and psychiatry}

Once literature has pointed out contradictory aspects surrounding the complex nature of the object, functions, efficacy, effective staff training and educational programs of spirituality issues in the mental health scene, one expected result of these 
set of factors would be an impaired practical care. Thus, "services and staff often neglect this area"(26), or they just reflect the characterized conflicting scheme, as shown in empirical evidence: "serendipitous finding was that mental health nurses were able to describe the ideal spiritual interventions, but they have reported fewer instances when they actually have inter-

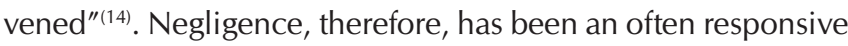
phenomenon to spiritual needs in the mental health field of assessment and interventions ${ }^{(1)}$.

The compound body of empirical evidence ${ }^{(14,20,22,24)}$, studies

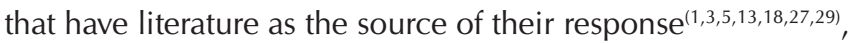
adding the mixed methodological study that measures variables during the application and evaluation of a training program in this area $^{(26)}$, set up the negligence in aspects of denial, disregarding, unfamiliarity and unavailability. All of them imply in ignoring "the whole dimension of care"(18) and maintaining the unmet conduct of spiritual needs of the mentally ill(27).

In reference to the denial property of the negligence phenomena, it has been said that carers consider this kind of need not a standard repertoire or an issue of their main responsibility ${ }^{(18,29)}$. Thus, If it is not a nursing task to meet spiritual needs, it could be disregarded, suppressed, or a forgotten task in an initial evaluation and treatment plan, and not faced as well-being factors ${ }^{(3,18,27)}$. Reflecting educational problems on the subject, unfamiliarity occurs causing avoidance and unavailability ${ }^{(5,13,20,22,24)}$. Unavailability is related to time and insufficient or ineffective resources provision ${ }^{(13,22,24)}$. Pullen, Tuck and Mix pointed out four identified reasons of negligence that could summarize this point: "nurses lack self-spiritual awareness; fear of imposing personal beliefs on the client; time constraints; lack of nursing education in spirituality interventions"(13).

\section{Feelings and fears about the management of spirituality}

There are some reported feelings about nursing engagement with clients' spiritual needs: the reluctance on talking about spiritual subjects ${ }^{(29)}$; a reserved attitude moved by "fear of imposing personal beliefs on the client" ${ }^{\prime \prime 13)}$. Fear could also be the factor beyond the reason why nursing staff uses "caution to encourage patient's beliefs", that is, fear of faith disagreement, or even "fearing that spirituality might trigger psychiatric symptoms"(27). Studies have also shown some kind of discomfort in staff when they are trying to lead with the scope of the client's spirituality ${ }^{(19,22)}$.

The literature guides, principals, views and interventions on how to lead the caring with psychiatric and mental health patients

\section{The views}

\section{The holism and whole person: a human being view}

Holism is an applied concept to health care in which assistance to individuals should be given according to the integration of their needs in a person-centered approach ${ }^{(1,26)}$. In source literature the following words were identified to describe the framework that distinguishes the grouping of needs into dimension $^{(5,24)}$, perspectives ${ }^{(14,17)}$, levels of functioning ${ }^{(26)}$, elements ${ }^{(8)}$, $\operatorname{aspects}^{(8,14)}$, multidimensional ${ }^{(19)}$, multilayer and multilevel ${ }^{(1)}$.
Those terms refer to the integration of physical and biological; social; psychological; environmental; or bio psychosocial; and spiritual; or simply body, mind and spirit ${ }^{(1,5,8,14,17,19,22,27)}$.

Nursing care is anchored in holistic tradition since Nightingale $^{(13,17)}$ and her vision of a human being. Presently, holism is current in models and theories of nursing or just an applied aim of nursing care $^{(1,8,10,14,24,26)}$. Holistic care is the fundamental concept of spiritual caring or the conception that provides the justification in addressing spirituality in health and mental health" ${ }^{(26)}$. Holistic care in mental health "was defined as one that recognizes people with mental health problems as complete people" with its interrelations. This is a specific criterion in the vision of illness, and its consequence is individual valorization and preservation of his/her dignity. Holistic vision of illness contradicts the biological Cartesian approach where disease is seen as damage to the body or its corruption. In a holist approach the individual is a complete person, not considered in separated departments of knowledge, for "inseparability is an essential characteristic of the holistic viewpoint"(5). At the end of last decade, Holistic care in mental health was proclaimed as a nursing challenge in response to the new setups of our times ${ }^{(8)}$.

A caring approach of the mentally ill in holistic care considers the whole experience in "every dimension of his or her existence ${ }^{\prime \prime(5)}$ and, for that, the spirit could not be ignored also being a focus of a person-centered holistic way and a key point ${ }^{(26-27)}$. In fact, authors state that mental health patients express their spiritual needs ${ }^{(26)}$, or they could be acknowledged requiring respect and intervention in a patient-centered holistic approach ${ }^{(1)}$.

\section{The view of practice}

The literature set up conditions to enable spiritual care in mental health in an equilibrium between psychopathological medicine science with its use of symbolic subjectivism and art of care ${ }^{(3,15)}$. The psychopathologist Karl Jaspers and the neurologist-logotherapist Victor Frankl are mentioned here. Jaspers "inclines mental health practitioners to enter into the subjective experience of their clients, rather than limiting their engagement to the objective measurement of bodily or mental states $^{\prime \prime(15)}$, and to do it means to engage in a comprehension of the patient symbolic system of values as transcendence and meaning, place of Frankl's explanation.

In this sense, life events as crises and illnesses are taken in practice as opportunities of spiritual growing and transformation $^{(28)}$. In this type of practice "the guiding principle of human caring is to view the individual as a spiritual being"(20), as stated by the Mental Health Foundation in 1999.

\section{The view of advantages}

We collected a short list containing advantages of spiritual ways in approaching mental illness based in two distinct studies. The first one relies in the experience of self-supporting groups in mental health as Alcoholics Anonymous. These groups utilize spiritual practices (self-knowledge, sharing, reflection, prayer, meditation) ensuring lower or non-cost in terms of treatment accessibility, non-stigmatizing, rising peace of mind, sense of purpose, transformation of hurt into concern for others, acceptance and non-judgmental disposition ${ }^{(23)}$. 
The second study is based on the character assessment of a spiritual experience in psychiatric patients ${ }^{(9)}$. It points out how a spiritual experience should be considered "since it may give insight into the individual and their illness". This information corroborates with others already presented here as far as spirituality to be a way of understanding the inner functions of the individual with its symbolic system of values and meaning.

\section{The view of manuals, models/theories and agencies}

Guides, manuals, theories and models for Mental Health and Psychiatric Caring are published for expertizes and agencies to provide a pool of principles about spirituality reflecting holistic and humanized concept, as an effort to equip clinical practioneers (Chart 2).

In terms of health political orientation, we found statements extracted from the National Institute for Mental Health in England (2003) and The Nursing and Midwifery Council. National Institute "identified spirituality as being vital to the recovery of a person experiencing mental ill health"; and the Nursing Council "instructs that nurses duty is to ensure that the spiritual needs of individual to be addressed"(24).

\section{The view of the client}

Finishing the views that advocate for the nursing addressing of spiritual needs in Mental Health and psychiatry, two authors also descrambled the view of clients. First, it is a question of importance: "People with mental health needs are increasingly identifying spirituality as a vital part of their recovery"(24). Secondly, it is a guidance issue to be regarded in its ethical circumstances: "nurses' clients depended on the nurse for spiritual guidance ${ }^{\prime \prime(14)}$; It does not mean any possibility of faith imposing, but in a direction of person-centered and holistic approach, nurse will deliver client need with respect and promoting his/ her autonomy.

\section{Literature in spirituality and caring interventions on psy- chiatry and mental health}

Spiritual Assessment and Therapeutic Plan in Mental Health Assessment of spirituality is a nursing intervention ${ }^{(19,22)}$ to "determine the patient's denomination, beliefs, and what spiritual practices are important to the patient"(3). Or simply, it is to take the history ${ }^{(19)}$. Assessment in Tidal Model concept is an intervention in which spirituality is not a field apart but an integrated one. Assessment would cover three domains: 1) the Self Domain is a "person's private world and experience of the immediate crisis and need for safety"; 2) World Domain, "the social place where people share their private self with others"; 3 ) the Others Domain, "where the person interacts and engages in interpersonal encounters"(28).

An assessment should proceed in a performed connectedness that is more important than methodological stuff or tools for eliciting a spiritual discussion with the client ${ }^{(19)}$. Efforts should be employed "to facilitate patients to express their spirituality", and Elliot also reminded that patients talk in an open-ended metaphoric way to describe their spirituality ${ }^{(24)}$. In order to facilitate the relationship, "patients prefer that therapists have knowledge regarding their beliefs" ${ }^{\prime(3)}$. A case-by-case approach should be considered to and the result should never cause harm ${ }^{(3)}$.

A special attention should be dispensed on how to judge information during the assessment. Elliott cites the "bias problem" and gives the example on the use of the word "delusion", he wrote. It could be a misinterpretation of someone's belief (24). Actually, Ledger asserts about the phenomena among users "reluctant to express their spiritual needs and religious beliefs because they fear this may lead to increased medication and longer hospital stays"(26). We call the attention to the specific DSM section that distinguishes religion, cultural experience and pathology. In considering the assessment of florid symptomatic patients, spiritual assessment trends to fall short ${ }^{(24)}$.

Chart 2 - Spirituality in Psychiatry and Mental Health: Models, Manuals and Theories as they are registered on Literature

\begin{tabular}{|c|c|c|c|c|}
\hline What & Reference \# & Class & Contribution & Proprietary \\
\hline DMS & $(19,25)$ & $\begin{array}{l}\text { Diagnose } \\
\text { Manual }\end{array}$ & $\begin{array}{c}\text { Concern under difference between pathology and } \\
\text { religion experience and transcultural issues. Religion } \\
\text { in mental health patient. }\end{array}$ & $\begin{array}{l}\text { American } \\
\text { Psychiatric } \\
\text { Association }\end{array}$ \\
\hline NANDA & $(3,14-15,23)$ & $\begin{array}{l}\text { Diagnose } \\
\text { Manual }\end{array}$ & $\begin{array}{l}\text { Diagnose of Spiritual Distress and Potential for } \\
\text { Enhanced Spiritual Well-being. }\end{array}$ & $\begin{array}{l}\text { North American } \\
\text { Nursing Diagnose }\end{array}$ \\
\hline $\begin{array}{l}\text { Theory of Human } \\
\text { Becoming }\end{array}$ & (19) & Theory & Holistic approach on client and health. & $\begin{array}{l}\text { Rosemarie Rizzo } \\
\text { Parsee }\end{array}$ \\
\hline $\begin{array}{l}\text { Science of Unitary Human } \\
\text { Being and Spirituality }\end{array}$ & $(10)$ & Theory & $\begin{array}{l}\text { Spirituality in advanced practice nursing, human } \\
\text { pandimensionalist concept. }\end{array}$ & Marta E. Rogers \\
\hline Theory of Hope & (8) & Theory & Holistic framework elements to promote health & Anthony Scioli \\
\hline Tidal Model & $(28)$ & Model & $\begin{array}{l}\text { Based on midrange theory, it proposes six guide } \\
\text { principals focused on empowering patient in care } \\
\text { and life experience, spirituality place. }\end{array}$ & $\begin{array}{l}\text { Phil and Poppy } \\
\text { Barker }\end{array}$ \\
\hline 12 Steps & $(19)$ & Model & $\begin{array}{c}\text { Self-support group } \\
\text { Transcendence in terms of connection with high } \\
\text { power and others }\end{array}$ & $\begin{array}{l}\text { Anonymous } \\
\text { alcoholic }\end{array}$ \\
\hline
\end{tabular}


Eeles, Lowe and Wellman set the explanatory modes "reported by nurses when they try to understand mental illness and spiritual experience": 1) their own beliefs; 2) intuition rooted on subjective analysis of the evaluated; 3) psychological or physical approach; 4) a diagnostic route ${ }^{(9)}$. This set could offer a guide of bias sources, and avoidance of them as a primary parameter should be surpassed by a patient-centered approach; and even in a dramatic assessment during a florid mystical discourse an attention to symbolic inner structure should be accounted; or it should serve as a bond to the next subjective point of need.

Spiritual assessment could help in an elaboration of a more individualized treatment plan $^{(3)}$ and the information would be useful to psychotherapeutic interventions ${ }^{(3)}$. Some related cases reported in literature are evidence of how effectiveness was increased due a well-made assessment ${ }^{(3,10,16,23,28)}$. One such assessment provided the catholics context of an inpatient lady with a compulsive use of the rosary. Information helped the staff to introduce, through a didactic intervention, a deep breathing pause between rosary prayers, what caused patient relaxing and opened the way to evolution $^{(3)}$. Cox also related about a schizophrenic man that would not lie in bed to sleep. The sir used to rustle the hymn "Come to Jesus". Staff started to play some gospels songs to him what soon promoted him a good sleep in bed ${ }^{(10)}$.

Chaining the scope of our findings, the holistic patient-centered approach, the functions of spirituality in the human being, the whole set of boundaries, and even more the psychiatric clinic patients, it is really impressive that there is a door open in literature to adopt therapeutic elements of spirituality, benefits that reflect what have been subtly done in practice and contradicting what before was understood as reality orientation ${ }^{(3,10)}$. It appears evident that, among the field on the care of the mind, addressing spirituality is more a theoretical effort instead of a set of evidence.

Nevertheless, there are reported cases that sustain literature orientation as assessment could allow a therapeutic plan to include addressing spiritual practice in matter of mental health benefit. Some of those orientations are: daily spiritual activity focused on comfort and relief or as a coping attitude $\mathrm{e}^{(1,3)}$.

\section{Assessment tools}

Literature provides some tools for spiritual assessment; however it makes cultural, methodological and functional reserves. Elliot states that "recognized assessment methods are limited to what a person believes and how it may be expressed"(24); we could call it as a restriction of functioning. Raffay expresses a list of limitations correlated to tools designing; they are modeled in general hospitals wards and are not validated to psychiatric patients due to the absence of evidence about their outcomes as well as insufficient guidance ${ }^{(7)}$. When their use is adopted, they require adaptation to client context and needs ${ }^{(24)}$.

Assessment spiritual tools are short, brief guides to collect spiritual experience of client; they are HOPE, HOPES, FICA and FACT. We added here the Red's "Spiritual Perspectives Scale", not listed among assessment tools to clinical settings but used on data collection in crossing descriptive studies; thus, it has importance as spiritual assessment tool of nursing teams. This instrument is a likert-type scale of six degrees in a questionnaire of 10 items that measures one's spiritual perspective and how spirituality permeates someone's life ${ }^{(13)}$.

HOPE is an acronym to the assessment questionnaire focused on Sources of Hope, Organized Religion, Personal Spirituality and practices, Effects on care and end-of-life ${ }^{(3,7,19,26)}$. HOPES is an expanded form of HOPE added the "S" of support, "to ensure that the questions arise for better utilization or welfare" ${ }^{\prime \prime(7)}$. The acronym $\mathrm{FICA}^{(7,19,26)}$ is "designed to help practitioners to structure questions when taking a spiritual history - Faith (kinds of beliefs), importance (how important), community (membership or affiliation), address (what client would like to be addressed)"(3). Raffay says "HOPE and FICA have the advantage of being memorable and thus are more readily usable in real-life clinical settings"(7). The only reference to LaRocca-Pitts' tool, the FACT, says it is just a "Spiritual History Tool" that prioritizes spiritual treatment on clinics ${ }^{(7)}$.

\section{Reported spiritual practices with clients}

What to do for a patient for whom a spiritual practice could be beneficial. First of all, it should be an elemental retry of an ethical consideration under a patient-centered practice and holistic view. As a matter of fact, this answer starts on the expressing of own patient ${ }^{(29)}$, and it is balanced within the limits of the profession and a humanized technical discernment of the caregiver.

Tuckl, Pullen and Wallace compared the spiritual perception of a mental health team with parish nurses The measurement of interventions reported by the mental health nurses was classified as ideal, with the prerogative to be the best ones; the general or most common, and specific interventions that nurses could remember of having done just the prior days of the test ${ }^{(17)}$. This classification would be compared to grammar adjective rules and would be the subjective quality of intervention.

Following the grammar rules, one set of needs require specific modes for when to act - what affects the time, as an adverb. Anchored in the theoretical bases of The Cultural Relational Theory, and written in Christian Confessional perspective, also addressed to confessional Christian Nurses, Schuhow reflection recommends when interventions should occur by their type ${ }^{(21)}$ : 1) Immediately, nurses could pray with client, offer listening or referring to a listening to promote client expression of his/her hurting; 2) In short-term, the sacred and inspiring reading; 3) In long-term, connection to higher forces and powers.

About the whole set of practices that could be done as interventions for supplying spiritual needs, or developing of client spiritual practices, we could collect the following ones:

Tell Bible or sacred stories. Aftonomomos is a Christian overnight caring for a girl with bipolar disorder. Attending to the girl's request, the nurse told her some bible stories, which opened communication and a therapeutic relationship ${ }^{(16)}$. Keeping a conversation assured the presence of the nurse, which is one category reported by nursing when were elicited to inform about spiritual interventions ${ }^{(14)}$. Presence means the nurses being with the client (the presence of nurse). Presence is a form of intensive care. For this reason, it requires caution and serenity, a non-judgmental attitude, talking, touching, listening, caring, supporting, understanding, and respecting ${ }^{(14)}$. These are the tools for intensive presence. These offer the client the physical and emotional presence of the nurse. 
Referring to chaplain and religious staff(7) is another possibility. Less intensive, but yet a dispense of attention, referring adopted the schema of valorization. It is a result of listening, and should not be used as a deferral of responsibility or an expression of negligent tendency. Referring is support to a need, a combination of multidisciplinary skills and practices to better attend a client and improve his/her health. In this sense, it means doing for the client, a caring demonstration of performing on the client's behalf and including is the nurse using time, people, and space to provide care ${ }^{(14)}$.

All of the practical ways should result in client encouraging (look insight for strength). Praying, attending of religious activities, talking about spirituality, reading ${ }^{(14)}$ should be a seeking of inner strength. To the list of Tuck and colleagues, it could be added meditation, inspiration, orientation, or others practices of peace and strength. Encouraging the client to look outward (for people and objects that could be resources for them), gives to the client responsibility on how to seek for community resources as ministers, social workers, chaplains, and clergy ${ }^{(14)}$. Whatever the practice, its consequences should be linked for the commonly positive effect founded in literature ${ }^{(29)}$.

Expected results are an implementation and fomentation of a Therapeutic Relationship ${ }^{(16,20)}$. Tell stories, be present or respond to the spiritual needs is to meet the client and earn his/her confidence and opening. Patients in the mental area are severely compromised in their affections, what is a point to set up a relationship in a euthymic system to the client. Koslander and Arvidsson assert the networking caring and clients should be characterized by love.

Hope, strength, growing, and other spiritual virtuosities cited here, have psychological implications and coping. Even when the mental suffering is taken by network client and caring as an opportunity of learning with the undeserved ${ }^{(23)}$, as it is done in the moral teaching of epic Hebrews poem of Job. Cox says: "the aims of holistic and spiritual engagement of nursing is to reduce the impact of disease and to promote health and the prevention of disease; this approach to all humans make nursing a unique contribution"(10). More than an inoperative declaration, it is the desired result for any intervention; it comes to promote in the client the reducing of the disease's impact and the increasing of the client's health.

\section{The staff necessary skills}

In matter to insure best results, literature asserts a set of necessary staff skills when it is dealing with clients' spirituality. The first one is communication. Deep listening (active attentive, genuine, and comprehensive) even when talking is generated in terms of psychotic symptom, requires self-awareness for communication to be always hopeful, a conduction of spiritual growth ${ }^{(5,14)}$, what here is understood as transcendental increasing of connection with the sacred, self, and common life, that result in an incrementally modulation of meaningful function to existence. Communication in this sense of performance and target should be pervaded for intuitive spiritual elements as sensitivity and creativity ${ }^{(19)}$. Communication should be "worded so as to encourage participation and convey respect"(24).

Ethics is an already consideration, the come together of others propositions. In synthesis, it includes the perception and attitudes that govern the caring practice with respect, acceptance, and nonjudgmental in the whole complex of a positive and negative framework where spiritual matters affect the individual. In such complex boundary line, a special kind of awareness drown for sensitivity ${ }^{(25)}$, so that it would be called for insight or clairvoyance. Awareness could be to this extent a high level of perception not to just distinguish the influence of psychosis; moreover, what this influence in the system of meaning could tell about a client and to be helpful in an ethical regard. Less than that, perception is just to have awareness, to know, clients' spiritual needs ${ }^{(1)}$.

\section{CONCLUSION}

The literature about Spirituality on Mental Health caring in this study lead us to discover Spirituality as an elementary human need worthy of proper attention in its multiple consequences for the human symbolic system of representing life and its propose. Spirituality is connectedness of the transcendental consciousness to the deep self, high powers and deities as well as to the world. It influences the humor, socialization, cultural conceptions and conditions of health. Such large dimension requires professional sensitivity and accurate assessment as management in Mental Health Care is implicit in many antagonistically clinical specifications that require deep attention of carers.

According to the material collected for this study, it becomes clear that spirituality in caring issues has been explored more in theory than in the practice field. It remains scarce the body of empirical researches correlating care, spirituality and Mental Health to demonstrate how spiritual practices in care settings as prayers, meditation, talking and others can affect the mental state.

However, it is clear the trends adopted in theoretical literature have pointed out the holistic foundation of actual nursing and its concern to the whole human being where spirituality has a main role. Literature is consistent to indicate the demand for education in spirituality caring for Mental Health professionals and how the few instances do not overcome the present status of resistance, estrangement and a negligent posture in attempting to meet spiritual needs, mischaracterizing the nursing field in relation to its new trends.

It appears that nursing in Mental Health is fixed in an intermediate conception of its history, influenced by the psychopathological orientation of a specific remote time, and not by the actual concerns as new versions of DMS have demonstrated as well as the nursing researches. Nevertheless, it is important to add the point about the complaint received through some filed researches where carers pointed out the mischaracterization of the nursing role by services structures, what implies the restriction of the necessary conditions to play the humanistic caring function properly. This, call us to reflect about the conflict between theoretic trends and material constitution. Such trend of theory over constitution could reflect in the asking of the nursing field to return to its classic humanistic objective, now equipped with scientific bases too; this would ensure nursing with a higher performance of this very specific role. These findings in literature of Mental Health settings could be just the tip of the iceberg of a deeper discussion on the role that nursing should be taken in an idealistic over materialistic discussion. 
In a few instances, it is necessary to recall that spiritual needs has a large distention of psychotic phenomena, and to put out that pathological distortion connected to spiritual elements can be properly managed too. As scholars affirm, our times concentrate such a comprehension of the human being and should respond to its need in a holistic approach. These important conceptions shall guide practice and training in the Nursing Mental Health Care.

\section{REFERENCES}

1. Mohr WK. Spiritual issues in psychiatric care. Perspect Psychiatr Care[Internet]. 2006[cited 2016 May 2];42(3):174-83. Available from: http://dx.doi.org/10.1111/j.1744-6163.2006.00076.x

2. Greenberg D, Witztum E, Buchbinder JT. Mysticism and psychosis: the fate of Ben Zoma. J Med Psychol[Internet]. 1992 [cited 2016 May 2];65(Pt-3):223-35. Available from: https://www.ncbi.nlm.nih.gov/pubmed/1390356

3. McLaughlin D. Incorporating individual spiritual beliefs in treatment of inpatient mental health consumers. Perspect Psychiatr Care[Internet]. 2004[cited 2016 May 2];40(3):114-9. Available from: https://onlinelibrary.wiley.com/doi/abs/10.1111/j.1744-6163.2004. tb00005.x

4. Cook $\mathrm{CCH}$. Religious psychopathology: The prevalence of religious content of delusions and hallucinations in mental disorder. Int J Soc Psychiatry[Internet]. 2015[cited 2016 May 2];61(4):404-25. Available from: https://www.ncbi.nlm.nih.gov/pmc/articles/ PMC4440877/

5. Thompson I. Mental health and spiritual care. Nurs Stand[Internet]. 2002[cited 2016 May 2];17(9):33-8. Available from: https:// www.ncbi.nlm.nih.gov/pubmed/12478921

6. Koenig HG. Religion, spirituality and psychotic disorders. Arch Clin Psychiatry[Internet]. 2007[cited 2016 May 2];34:95-104. Available from: http://www.scielo.br/pdf/rpc/v34s1/en a13v34s1.pdf

7. Raffay J. How staff and patient experience shapes our perception of spiritual care in a psychiatric setting. J Nurs Manag[Internet]. 2014[cited 2016 Jan 5];22(7):940-50. Available from: https://www.ncbi.nlm.nih.gov/pubmed/23611737

8. Stuart GW. Mind to care and a future of hope. J Am Psychiatr Nurses Assoc[Internet]. 2010 [cited 2016 May 2];16(6):360-5. Available from: http://journals.sagepub.com/doi/abs/10.1177/1078390310390363

9. Eeles J, Lowe T, Wellman N. Spirituality or psychosis? an exploration of the criteria that nurses use to evaluate spiritual-type experiences reported by patients. Int J Nurs Stud[Internet]. 2003[cited 2016 May 2];40(2):197-206. Available from: https://linkinghub.elsevier. com/retrieve/pii/S0020748902000615

10. Cox T. Theory and exemplars of advanced practice spiritual intervention. Compl Ther Nurs Midwifery[Internet]. 2003 [cited 2016 May 2];9(1):30-4 5p. Available from: https://www.ncbi.nlm.nih.gov/pubmed/12604323

11. Lepherd L. Spirituality: everyone has it, but what is it? Int J Nurs Pract[Internet]. 2014[cited 2015 Jun 23];21(5): 566-74. Available from: https://onlinelibrary.wiley.com/doi/abs/10.1111/ijn.12285

12. Whittemore R, Knafl K. The integrative review: updated methodology. J Adv Nurs [Internet]. 2005 Dec 1 [cited 2016 Jan 6];52(5):54653. Available from: http://onlinelibrary.wiley.com/doi/10.1111/j.1365-2648.2005.03621.x/abstract

13. Pullen L, Tuck I, Mix K. Mental health nurses' spiritual perspectives. J Holist Nurs[Internet]. 1996 [cited 2016 May 2];14(2):85-97 13p. Available from: https://www.ncbi.nlm.nih.gov/pubmed/8708349

14. Tuck I, Pullen L, Lynn C. Spiritual interventions provided by mental health nurses. West J Nurs Res [Internet]. 1997 [cited 2016 May 2];19(3):351-63. Available from: http://journals.sagepub.com/doi/abs/10.1177/019394599701900306

15. Nolan P, Crawford P. Towards a rhetoric of spirituality in mental health care. J Adv Nurs [Internet]. 1997[cited 2016 May 2];26(2):289_ 94. Available from: https://www.ncbi.nlm.nih.gov/pubmed/9292362

16. Aftonomos S. Dancing with Dianna. J Christ Nurs[Internet]. 1999[cited 2016 May 2];16(3):22-3. Available from: https://europepmc. org/abstract/med/11912649

17. Tuck I, Pullen L, Wallace D. A comparative study of the spiritual perspectives and interventions of mental health and parish nurses. Issues Ment Health Nurs [Internet]. 2001[cited 2016 Jan 5];22(6):593-605 Available from: https://www.ncbi.nlm.nih.gov/ pubmed/11881517

18. Greasley P, Chiu LF, Gartland RM. The concept of spiritual care in mental health nursing. J Adv Nurs [Internet]. 2001 [cited 2016 May 2];33(5):629-37. Available from: https://onlinelibrary.wiley.com/doi/abs/10.1046/j.1365-2648.2001.01695.x

19. O'Reilly ML. Spirituality and mental health clients. J Psychosoc Nurs Ment Health Serv [Internet]. 2004 [cited 2016 Jan 5];42(7):44-55 12p. Available from: https://www.ncbi.nlm.nih.gov/pubmed/15295917

20. Koslander T, Arvidsson B. How the spiritual dimension is addressed in psychiatric patient-nurse relationships. J Adv Nurs[Internet]. 2005 [cited 2016 May 2];51(6):558-66. Available from: https://www.ncbi.nlm.nih.gov/pubmed/16129006

21. Schuhow DA. Even Christian women get depressed: how can we help? J Christ Nurs[Internet]. 2007[cited 2016 May 2];24(2):76-80. Available from: https://www.ncbi.nlm.nih.gov/pubmed/17432336 
22. Brimblecombe N, Tingle A, Tunmore R, Murrells T. Implementing holistic practices in mental health nursing: a national consultation. Int J Nurs Stud[Internet]. 2007 [cited 2016 May 2];44(3):339-48. Available from: https://linkinghub.elsevier.com/retrieve/pii/ S0020-7489(06)00238-0

23. Baumann SL. Recovering from abuse: a comparison of three paths. Nurs Sci Q[Internet]. 2007[cited 2016 May 2];20(4):342-8. Available from: https://www.ncbi.nlm.nih.gov/pubmed/17911332

24. Elliott R. Spirituality, mental health nursing and assessment. J Community Nurs [Internet]. 2011 Jun 5 [cited 2016 Jan 5];25(3):4-10 5p. Available from: https://trove.nla.gov.au/work/153027872?q\&versionld = 166764185

25. Murakami R, Campos CJG. Religion and mental health: the challenge of integrating religiosity to patient care. Rev Bras Enferm[Internet]. 2012 [cited 2016 May 2];65(2):361-367 7p. Available from: http://www.scielo.br/pdf/reben/v65n2/v65n2a24.pdf

26. Ledger P, Bowler D. Meeting spiritual needs in mental health care. Nurs Times[Internet]. 2013 [cited 2016 May 2];109(9):21-3. Available from: https://www.ncbi.nlm.nih.gov/pubmed/23550487

27. Tokpah MM, Middleton L. Psychiatric nurses' understanding of the spiritual dimension of holistic psychiatric nursing practice in South Africa: A phenomenological study. Afr J Nurs Midwifery [Internet]. 2013[cited 2016 May 2];15(1):81-94. Available from: http://uir.unisa.ac.za/handle/10500/13037

28. Kilmer DL, Lane-Tillerson C. When still waters become a soul tsunami: using the Tidal Model to recover from shipwreck. J Christ Nurs[Internet]. 2013[cited 2016 May 2];30(2):100-4. Available from: https://www.ncbi.nlm.nih.gov/pubmed/23607157

29. Lee E, Zahn A, Baumann K. How do psychiatric staffs approach religiosity/spirituality in clinical practice? differing perceptions among psychiatric staff members and clinical chaplains. Religions[Internet]. 2015 [cited 2016 May 2];6(3):930-47. Available from: http://www.mdpi.com/2077-1444/6/3/930

30. Pullen L, McGuire S, Farmer L, Dodd D. The relevance of spirituality to nursing practice and education. Ment Health Pract[Internet]. 2015 [cited 2016 May 2];18(5):14-18 5p. Available from: https://journals.rcni.com/mental-health-practice/the-relevance-ofspirituality-to-nursing-practice-and-education-mhp.18.5.14.e916 